\title{
End of consensus? Ideology, partisan identity and affective polarization in Finland 2003-2019
}

\author{
Daniel Kawecki \\ University of Helsinki \\ daniel.kawecki@helsinki.fi
}

This is the pre-peer reviewed version of the following article: Kawecki, D. (2022). End of consensus? Ideology, partisan identity and affective polarization in Finland 2003-2019. Scandinavian Political Studies, 1-26, which has been published in final form at https://doi.org/10.1111/1467-9477.12238. This article may be used for non-commercial purposes in accordance with Wiley Terms and Conditions for Use of Self-Archived Versions."

\section{Data availability statement}

The data that support the findings of this study are available in Finnish Social Science Data Archive at https://services.fsd.tuni.fi/, reference numbers FSD1260, FSD2269, FSD2653, FSD3067, FSD3467.

\section{Funding statement}

This research was funded and supported by the Society for Swedish Literature in Finland and by a grant awarded by Nylands Nation [2020].

\section{Conflict of interest disclosure}

The author has no conflicts of interests to declare. 


\section{Abstract}

Finland is traditionally associated with a consensus-like political culture, low partisan hostility and consistent levels of ideological polarization. Despite this, concerns about political polarization are widespread. A possible explanation is that affective polarization, a phenomenon characterized by increasing emotional distances between political groups, is increasing. This paper examines trends and individual level predictors of affective polarization in the Finnish electorate between 2003 and 2019, using survey data from five national election studies. Additionally, it contributes to the theoretical understanding of affective polarization in multiparty settings by introducing a measure based on the absence of neutrality towards parties.

The results show a general increase in affective polarization over the period and identifies ideological extremity as the main predictor of the phenomenon. While the impact of ideological positions on the left-right scale didn't change according to any discernible pattern over time, positions on the GAL-TAN scale begun driving affective polarization in 2011. The importance of sociocultural issues has since increased and having a strong TAN position became the strongest predictor of affective polarization in 2019. Feeling close to a party had a more consistent effect on affective polarization, albeit not as large as ideological extremity.

Increasing affective polarization might undermine the prevailing consensus culture in Finnish politics. However, it might also have positive effects as a corrective to voter apathy, leading to increased participation. This makes Finland an interesting case for further studies of the causes and effects of affective polarization. 


\section{Introduction}

Concerns about political polarization have become widespread in Finland during the latest decade, yet studies show only minor increases in left-right polarization among voters (Isotalo et al., 2020) and no substantial changes along the most important issue dimensions among political candidates (Fornaro, 2021). Meanwhile, recent research has argued that political polarization is better conceptualized as the emotional rather than ideological distance between groups, a phenomenon known as affective polarization (Iyengar, Sood, \& Lelkes, 2012). This suggests that the concerns could be a reflection of increasing affective polarization (henceforth referred to as AP) rather than increasing ideological divides. A recent study by Kekkonen and Ylä-Anttila (2021) provides initial evidence that AP is indeed increasing between Finnish parties. Even so, little is known about this phenomenon in Finland, especially its foundations. The aim of this study is thus to examine the long-term development of AP in Finland, focusing especially on identifying the driving forces of the phenomenon in the Finnish context.

Since the 1980s, partisan relations in Finland have been characterized by consensus politics and low levels of conflict. This has been regularly manifested through the formation of oversized governing coalitions across traditional ideological divides. Consequently, parties have been reluctant to make strong pledges and to criticize each other too harshly during election campaigns as this could disadvantage them in the subsequent cabinet forming negotiations. (Karvonen, 2014: 73-106) While these observations concern parties themselves rather than party supporters, comparative studies (Reiljan, 2020; Wagner, 2020) show that affective polarization among Finnish voters is indeed low compared to other European countries. Finland thus presents itself as a case where affective polarization should be difficult to find.

At the same time, the traditionally low level of partisan hostility in Finland could also be interpreted as fertile ground for increased polarization. Finland has experienced similar changes as many other countries: the politicization of sociocultural issues (Westinen, Kestilä-kekkonen \& Tiihonen, 2016) and the break-through of the country's right-wing populist party in 2011. The government formations following the latest two elections indicate a growing divide between parties on the left/GAL-side and the right/TAN-side of the political compass. If these developments are reflected in growing affective divides between supporters of different parties, it could possibly spell the end of the prevailing consensus-oriented political culture.

The study is structured around the broad aim to understand the foundations and long-term development of AP among voters in Finland. Following in the footsteps of previous research, I focus on ideology and partisan identity as possible explanations of AP. When examining the ideological foundations, I differentiate between the socioeconomic (left-right) dimension, and the sociocultural (GAL-TAN) dimension of politics. The study of partisan identity will revolve around if feeling close to a party is relevant for affective polarization, not which party the voter identifies with. The relation of specific parties to affective polarization is thus beyond the scope of this study.

Apart from building upon to the modest previous knowledge of AP in Finland, this study contributes to the general understanding of the foundations of AP in European democracies in two ways. First, the case of Finland provides insights into the polarization process of countries with previously low hostility. Second, the study advances the theoretical understanding of AP in multiparty systems by building on approaches in previous research and proposing an interpretation of $\mathrm{AP}$ as absence of neutrality towards parties. 
The aim of the study can be broken down into four research questions, each addressing specific aspects of the long term-development and foundations of affective polarization in Finland. First, I seek to confirm previous results of affective polarization in Finland and ask whether the general level of AP has increased in Finland since the turn of the millennium (RQ1). Next, I break down the general trend and ask whether AP has increased broadly in the electorate, or if the development differs between groups of voters based on ideological position and partisan identity (RQ2). Third, I examine to what extent ideological position and partisan identity can explain differences in affective polarization among voters (RQ3). Lastly, I ask if the relative importance of different ideological positions and of feeling close to a party have shifted over time (RQ4). The answers to these questions will provide an overview of AP in Finland that allows for general conclusions about the phenomenon.

The study is based on data from the Finnish national election studies (FNES) covering the five national elections from 2003 to 2019. It proceeds as follows. The next section elaborates on the concept of affective polarization with special attention given to the voter level approach taken in this study, followed by a closer presentation of the Finnish political context. Thereafter, I present the data and variable operationalisations before proceeding to the analysis and discussion of the results.

\section{Affective polarization}

When Iyengar, Sood, and Lelkes (2012) introduced the concept of affective polarization they leaned on social identity theory, according to which a group identity manifests in the individual as an emotional attachment to the group one identifies with. This attachment creates a cognitive bias in favour of one's own group, known as the ingroup and gives rise to suspicion and animosity towards rivalling groups, the outgroups (Tajfel \& Turner, 1979). Thus, according to Iyengar, Sood, and Lelkes (2012), the emotional distance between parties is a result of both positive sentiment towards the ingroup and hostility towards the outgroup. Several studies of affective polarization in the US context show a substantial increase in especially negative affect between the Democrats and Republicans since the start of the new millennium (Iyengar et al., 2012, 2018; Iyengar \& Krupenkin, 2018; Iyengar \& Westwood, 2015). During recent years, studies of the phenomenon have also emerged in a European multiparty context (Harteveld, 2021; Hernández et al., 2019; Knudsen, 2020; Reiljan, 2016, 2020; Reiljan \& Ryan, 2021; Wagner, 2020; Ward \& Tavits, 2019), showing that the phenomenon is in no way unique to the United States.

\subsection{The foundations of affective polarization}

The research on the foundations of affective polarization has mainly followed two broad approaches: identity and ideology. The identity approach sees partisanship as a social identity and likens partisan behaviour to that of sports fans (Huddy et al., 2015; Mason, 2015), where supporting one's own team is the central aspect. In their pioneering study, Iyengar, Sood, and Lelkes (2012) found a consistent association of strong partisan identity with higher levels of affective polarization, as predicted by social identity theory. This association has been further confirmed by subsequent research, not least in the Swedish setting (Reiljan \& Ryan 2021; Renström, Bäck \& Schmeisser 2020) which resembles the Finnish case closely. The effect of partisan identity is further compounded when it aligns with ideological and other social identities (Mason, 2015, 2016).

The ideology approach does not have an equally well defined theoretical foundation, resting instead on the concept of "principled dislike" of outgroups based on their opinions (Iyengar, Sood \& Lelkes, 2012) and the 
assumption that ideological divergence raises the stakes and provokes emotions (Rogowski \& Sutherland, 2016). Bougher (2017) suggests belief congruence theory as a supplement to social identity theory, arguing that while inparty sympathy is best explained by social identity theory, outparty animosity is driven by systematic differences in beliefs rather than the distance between issue positions. Several studies have shown a link between ideological polarization/extremity and affective polarization (Reiljan, 2020; Rogowski \& Sutherland, 2016) and recent research on affective polarization in Sweden by Renström et al. (2020) and Reiljan and Ryan (2021) further confirms this association.

Previous research has also identified contextual, agentic and institutional factors associated with affective polarization. For example election campaigns, especially heated ones, drive affective polarization to higher levels (Hansen \& Kosiara-Pedersen, 2017; Hernández et al., 2019; Iyengar et al., 2012). This tendency is clearly visible in yearly Swedish affective polarization measurements that peak during each election year (Ryan \& Reiljan, 2018). Another line of contextual research suggests that media coverage of political polarization might increase affective polarization by driving more negative partisan attitudes (Levendusky \& Malhotra, 2016). McCoy and Somer (2019) discuss the agentic role of political elites in opting for strategies and discourse that drives polarization, and Gidron et al. (2020) demonstrate that affective polarization is generally higher in countries with majoritarian political institutions. Overall, these contributions show that affective polarization is driven by a complex mix of factors at multiple levels of analysis.

\subsection{Affective polarization in multiparty systems}

Affective polarization is intuitively understandable in an American two-party setting, while the multiparty settings common in Europe provide additional conceptual challenges. In a two-party setting, the polarization between both parties equals that of the party system, but in the multiparty setting we need to distinguish between polarization between different pairs of parties, and the polarization level of the party system itself. In practical terms, the researcher must define how to meaningfully summarise and interpret the feelings of voters towards a multitude of parties. This is a challenge that is mainly conceptual, but inevitably crosses partly into the territory of practical operationalization. The goal of the following discussion is thus to lay the foundations of an operationalization by arriving at an intuitively applicable understanding of affective polarization in multiparty systems and how this understanding manifests at the voter level.

Reiljan $(2016,2020)$ answers the challenge of defining affective polarization in multiparty systems by conceptualizing a system level measure called the Affective Polarization Index (API). This index calculates the average emotional distance between all parties in the party system weighted with party size, deeming in line with Dalton (2008) that polarization between large parties is more important from a system perspective than polarization between small parties.

Wagner (2020) moves the conceptual discussion further by observing that affective polarization has two meanings, referring either to the individual configurations of feelings towards parties, or to how these configurations add up to macro-level polarization. He proceeds to define the 'mean distance' approach to party system affective polarization by using the degree of sympathy towards the voters 'own' party as an anchor point for measuring the distances to the similar evaluations of every other party and calculating a mean distance.

The mean distance approach, especially when using weights for party size, is largely analogous with Reiljan's API. Both are intuitive as they build directly upon the dichotomous conflict between groups described by social 
identity theory and thus assumes that voters identify with a single party and perceive the other parties as opponents. The logic of the mean distance approach can thus be applied in the same way whether it is used to summarise partisan affect at the macro level or at the individual level. The main difference is merely one of which mathematical route to take: Reiljan aggregates the individual level measures at the party level before calculating a system index while Wagner moves directly from individual level to a system level index.

When using Reiljan's API/Wagner's mean distance, it is important to note that the macro-level pattern resulting from maximal polarization is not that of a bipolarized system, where two clusters of parties stand against each other. Instead, every party stands as far away as possible from every other party, resulting in what is best described as a fractionalized party system. The more parties in the system, the less the mean distance approach corresponds to the common idea of polarization as a force dividing society in two opposing camps. It is also a poor representation of the reality in many multiparty systems, where polarization often manifests as animosity between political blocs formed by several parties.

Consequently, Wagner (2020) argues that the mean distance approach doesn't capture a political reality in which voters can identify with several parties (Garry, 2007) or where bloc identities could be replacing specific partisan identities as the primary political identity (Hagevi, 2015). Inspired by Ward and Tavits (2019), Wagner (2020) proposes an alternative conceptualization of affective polarization as the extent to which the voter perceives the parties as divided into a bloc of liked parties and a bloc of disliked parties. He refers to this approach as the 'spread-of-scores', as it is based on how individual feelings are spread out between a group of liked parties and a group of disliked parties. This results in maximum polarization when voters perceive these groups to be of equal size and feel the maximum level of sympathy or animosity towards the parties in each cluster.

By introducing the spread-of-scores approach, Wagner admittedly deviates from the social identity foundation of affective polarization laid out by Iyengar, Sood, and Lelkes (2012). Instead of focusing on exclusive partisan identities, he uses the characteristics of macro-level bipolarization as a benchmark for assessing the extent to which individual feelings are polarized, and then aggregates individual level polarization levels into a country average. This approach does not display the same symmetry between the micro and macro levels found in the previously discussed mean distance approach; unless every voter perceives the same division between parties, there is no guarantee that an electorate of affectively bipolarized voters results in a bipolarized party system.

Wagner (2020) nonetheless demonstrates that the results from the spread-of-scores and the mean distance approaches are highly correlated and concludes that the choice between them is mainly a matter of theoretical choice. This choice introduces unnecessary uncertainty, as it will inevitably lead to certain polarized configurations of affect to be exacerbated and others to be downplayed. The choice can be distilled to whether a voter who strongly sympathises with a single party and dislikes all other parties is more polarized than a voter who strongly sympathizes with a cluster of several parties and strongly dislikes the rest of them. Fortunately, the necessity to make this choice can be overcome by instead focusing on a common property of both polarized configurations, namely the empty middle.

\subsection{Affective polarization as absence of neutrality}

A voter who sympathizes with a single party and opposes all the other parties has one thing in common with a voter who sympathizes with a bloc of parties against another bloc of parties: the empty middle that is the result of feelings clustering around two poles. This property emerges regardless of whether these poles contain one 
or many parties. This empty middle ground can be interpreted as absence of neutrality in the individual voter's attitudes towards the parties. Focusing on this characteristic rather than on the distribution of parties at each end of the scale, makes it possible to answer the question about which voter is more polarized with a "they are equally polarized".

The argument for the absence of neutrality is thus primarily one of increased validity. It overcomes the risk of misrepresenting certain polarized configurations by focusing on an intuitive property - absence of neutrality that is shared by a broader range of configurations. Furthermore, this approach disentangles the individual level from any inferences about patterns of macro-level polarization, stating simply that a polarized society is a society where voters lack neutral opinions about parties. Whether this results in system level fractionalization, bipolarization or something in between becomes an entirely different question, more suited for other ways of measuring affective polarization.

The absence of neutrality approach also retains the benefit of the spread-or-scores approach in recognizing that voters without specific partisan identities can also be affectively polarized, as long as they have both strong positive and negative feelings towards parties. This is especially relevant as affective polarization has also been linked to the phenomenon of negative partisanship, causing non-partisans to behave like partisans due to a strong dislike of political opponents rather than from a positive emotional attachment to any particular party (Abramowitz \& Webster, 2018).

\section{The political context}

Finland was not always a country characterized by consensus and broad cooperation. Having suffered a civil war at the beginning of its slightly more than 100 years of independence, the country is no stranger to the consequences of societal divisions running amok. These wounds healed slowly, and in the decades after the second world war, Finland was still characterized by deep divisions, culminating in the 1960s and 1970s when ideological differences between parties peaked (Karvonen, 2014:24,49). Nonetheless, dissolving collective class identities ultimately lead to the end of "the era of political camps" in Finland (Mickelsson, 2015). A series of comprehensive Incomes Policy Agreements that decreased industrial disputes and the rise of the oversized coalition as the norm for cabinet formation rapidly resulted in consensus becoming the overarching principle of Finnish political culture. (Karvonen, 2014:24, 38-40).

The Finnish party system never developed in the same bipolarized direction as in many of the Nordic neighbours. This could mainly be explained by the rivalry between the Social Democratic Party and the far left, preventing the formation of a ruling left coalition and instead forcing the Social Democrats to seek cooperation with one of the two other main parties (Karvonen, 2014:146-147), the agrarian Centre Party and the conservative National Coalition Party. The regular formation of oversized ruling coalitions, rather than minority governments, can further be explained by both constitutional factors that made it advantageous to secure a two-thirds majority in parliament, as legislation could otherwise be delayed by the opposition, and by active presidential influence encouraging cooperation (Karvonen, 2014:80). This norm has prevailed even though the constitutional rule that gave rise to it has been long abolished, leading Jungar (2002:78) to conclude that compromise and cooperation has become virtues in a Finnish political culture.

How does such a political culture reflect on the mass level? Karvonen (2014:150) notes that the backside of consensus and cooperation is that voters find it difficult to know "whom to thank and whom to punish in 
elections" and that the multi-layered institutional setting including parliament, president and the EU compounds the problem even more, creating an "impenetrable veil between citizens and the governing elite".

The parties currently available to the Finnish voter represent both the classical political divides and the postmaterialist questions that arose during the second half of the $20^{\text {th }}$ century. The traditional three major parties represent the social democratic, conservative and agrarian party families; The Social Democratic Party (SDP), The National Coalition Party (KOK) and The Centre Party (KESK). Since 2011, the right-wing populist (True) ${ }^{1}$ Finns Party (PS) is counted as a fourth major party. Furthermore, Finland has a left-wing party, a green party and a christian democrat party: The Left Alliance (VAS), The Green Party (VIHR), and The Christian Democrats (KD). However, the country currently does not have a classical liberal party of significant size. Even after several attempts at maintaining and reviving such parties, they have largely disappeared from the political scene, being replaced by the green party as the main alternative for urban liberals (Karvonen, 2014:19, 24).

Unlike its Nordic neighbours, the Finnish party system is also characterized by a historical language divide between the Finnish speaking majority and the Swedish speaking minority, where a majority of the latter supports The Swedish People's party (RKP). While created to politically represent the Swedish speaking population, this party has increasingly identified itself as liberal in both the cultural and economic sense during the 2000s (Mickelsson, 2015:304).

The two latest decades have been characterized by the increased importance of new conflict dimensions; the EU-dimension became more relevant simultaneously with the politicization of issues on the socio-cultural dimension such as immigration, diversity and the conflict between liberal and traditional values (Westinen et al., 2016). The 2003 election was the first after the adoption of a new constitution three years earlier. According to the new provisions, the parliament appoints the prime minister. The election was thus seen not only as a party election by the larger parties, but also as a prime minister election. The election campaign was, however, characterized by a cautious attitude, similar platforms and no far reaching pledges (Pesonen \& Borg, 2005). The following election in 2007 saw an increased use of digital communication tools such as websites and social media tools (Borg \& Paloheimo, 2009). Parties used more funds than before on campaigns and advertising, in what has been seen as a 'mediatization' of politics (Moring \& Mykkänen, 2009).

The 2011 election saw the unexpected success of the right-wing populist Finns Party. The party can trace its roots back to rural populist movements of previous decades (Karvonen, 2014:22). At the beginning of the 2000s, the Finns Party was nevertheless small with only a few seats in parliament. The election success in 2011 made it one of the largest parties in parliament, thereby changing the balance of power. The reasons for this success were manifold, and include the rising importance of questions pertaining to the new sociocultural conflict dimension such as immigration, in combination with a yearning for political change in general (Borg, 2012).

The 2015 election was preceded by shifts in the leadership of several of the major parties and by two of the coalition partners leaving the government over policy issues (Hämäläinen, 2016). The 2015 election itself did not lead to any dramatic changes in party support (Grönlund, 2016) and most of the public attention was directed at labour market and economic policy, and foreign policy (Railo \& Ruohonen, 2016).

\footnotetext{
${ }^{1}$ The party name Perussuomalaiset was regularly translated as the 'True Finns' until the party adopted 'The Finns' as its official English name in 2011.
} 
The 2019 elections where preceded by debates about immigration, European integration, the climate crisis, and an ongoing health, social services and regional government reform, as well as economic policy and elderly care. Strandberg and Borg (2020) find that the importance of the internet and social media strongly increased compared to previous elections, and Borg et al. (2020) further talk about a "political climate change" associated with growing discontent and distrust of both politics and the political system. At the onset of the 2020s, the Finnish electorate appears fragmented into multiple loosely delimited blocs with similar and partly overlapping partisan attitudes (Im et al., 2019; Kekkonen \& Ylä-Anttila, 2021; Westinen \& Kestilä-Kekkonen, 2015)

\section{Data and measurements}

I use data from the Finnish National Election Study (FNES). The study has been conducted after the five latest national elections in 2003, 2007, 2011, 2015 and 2019 through face-to-face interviews and a self-administered drop-off questionnaire. The data contains sociodemographic background variables as well as items related to political attitudes, voting choice, party identification and party sympathies. In total, the FNES data contains 7175 respondents divided between five elections (see online appendix A).

\subsection{Dependent variable: affective polarization}

Affective polarization, the dependent variable, is calculated based on attitudes towards parties measured on a 11-point like-dislike scale. The FNES question is worded: "What do you think about the following political parties on a scale $0-10$, where 0 means 'strongly dislike' and 10 means 'strongly like'?' The like-dislike scale is one of the most readily available tools for measuring affect towards parties as broad objects. This item is the basis for both Wagner's (2020) and Reiljan's (2020) measures of affective polarization. A similar item, although based on a 0-100 thermometer scale, is used in the bulk of the US-focused research.

As discussed in the theory section, approaching affective polarization as absence of neutrality towards parties requires that a voter who sympathises strongly with a single party and dislikes all the other parties is deemed as equally polarized as a voter who sympathizes with a bloc of parties and dislikes the rest of the parties. One solution would be to measure the standard deviation from the absolute middle of the scale rather than around the mean value of the scores, as in Wagner's spread measure. However, in a methodological evaluation of thermometer scales Winter and Berinsky (1999) cautions about using fixed neutral points as individuals may interpret the scale differently and anchor their evaluations in different points. When applicable, they propose that the researcher focuses on bias between groups, i.e. the difference in scores between the ingroup and the outgroup, rather than the absolute scores for each group.

With regard to this advice, I calculate each respondent's neutral point as the midrange value of the distribution of scores, using the most liked and the most disliked party as the de facto anchor points that represent the respondents understanding of the scale. I then calculate the standard deviation of all party scores around this point using the formula below. At least two like-dislike scores are required for the formula, which due to missing data results in 6870 out of the 7175 respondents having a valid affective polarization score. 


$$
\text { Affective polarization }(A B O N)_{i}=\sqrt{\frac{\sum_{p=1}^{P}\left(l i k e_{i p}-\frac{\text { like } e_{\text {max }, i}+l i k e_{\text {min }, i}}{2}\right)^{2}}{n_{p}}}
$$

Formula for Affective polarization as absence of neutrality (abon). $\boldsymbol{n}_{p}$ is the number of parties including the inparty. like $e_{i p}$ is the like score of the individual respondent (i) towards each party ( $p$ ). like $_{\max ,}, i$ is the highest like score of the individual respondent and like $\boldsymbol{m}_{\min , i}$ is the lowest score and the division with 2 results in the midrange value.

The maximum polarization score is 5 , given a like-dislike scale of $0-10$. This requires that at least one party is maximally liked (a score of 10) and at least one is maximally disliked (a score of 0 ), resulting in a midrange value of 5 . The rest of the parties must be scored at the maximum distance from this value, i.e. as either 0 or 10 . Table 1 demonstrates the calculated polarization scores for the absence of neutrality measure and compares them to Wagner's (2020) mean distance and spread scores ${ }^{2}$.

Table 1. Example of affective polarization (AP) scores with three different measures

Party scores (Party A-D): strong dislike (0) to strong like (10)

\begin{tabular}{cccccccc} 
id & $\mathbf{A}$ & $\mathbf{B}$ & $\mathbf{C}$ & $\mathbf{D}$ & $\mathbf{A P}$ (Abon) & $\mathbf{A P}$ (Dist/2)* & AP (Spread) \\
\hline 1 & 0 & 0 & 0 & 10 & $\mathbf{5}$ & 5 & 4,33 \\
2 & 0 & 0 & 10 & 10 & $\mathbf{5}$ & 4,08 & 5 \\
3 & 0 & 1 & 1 & 9 & $\mathbf{4 , 0 3}$ & 4,17 & 3,63 \\
4 & 2 & 4 & 6 & 8 & $\mathbf{2 , 2 4}$ & 2,16 & 2,24 \\
5 & 4 & 5 & 5 & 6 & $\mathbf{0 , 7 1}$ & 0,71 & 0,71 \\
6 & 2 & 2 & 2 & 2 & $\mathbf{0}$ & 0 & 0 \\
\hline
\end{tabular}

*Note: Wagner's mean distance measure ranges from 0 to 10, as ten is the maximum distance between scores. The result has been divided by two for comparability with the Abon and Spread measures, which range from 0 to 5 as they are based on the formula for standard deviation.

Rows 1 and 2 shows polarized configurations with the greatest absence of neutrality: all parties are perceived as either extremely liked or extremely disliked with nothing in between. Row 3 shows a slightly less polarized configuration. Note that both of Wagner's measures would rank order these configurations differently, depending on how well they match the theoretical conceptualization behind the measures. The rest of the table shows less polarized configurations. For these rows, Wagner's measures and the Abon measure provide similar results. When all parties are equally liked or disliked, as demonstrated in the last row, all measures result in a polarization score of 0 .

\subsection{Independent variables}

The independent variables capture respondents' positions on the left-right and GAL-TAN dimensions, and measure whether respondents have a partisan identity.

\footnotetext{
${ }^{2}$ Online appendix E contains the formulas and shows that all three approaches are in practice highly correlated $(r>0.9)$.
} 


\section{Left-Right position}

Ideological left-right position is determined by each respondent's self-placement on a 10-point scale, where 0 means left and 10 means right. Respondents were divided in five groups: Strong left (0-1), Leaning left (2-3), Center (4-6), Leaning right (7-8) and Strong right (9-10).

\section{GAL-TAN position}

The sociocultural conflict dimension is regularly represented by the GAL-TAN scale, referring to Green, Alternative and Libertarian values against Traditional, Authoritarian and Nationalist values (Hooghe et al., 2002). The FNES dataset has no self-placement item for this dimension. Instead, respondents' positions have been calculated as an index (scale $0-1$ ) across seven questions measuring attitudes towards traditional values, crime, ethnic minorities, sexual minorities, environmental policy, the EU and immigration. As with the leftright positions, voters were divided into five groups: Strong GAL (scores 0-0,24), Leaning GAL (scores 0,250,39), Center (scores 0,4-0,6), Leaning TAN (scores 0,61-0,75) and Strong TAN (scores 0,76-1)

The questions and response scales vary somewhat from year to year and the full list can be found in the online appendix D. Cronbach's alpha for the items ranges between 0,61 and 0,69 for the years 2011 to 2019. Before 2011, it reaches only 0,42 for 2003 and 0,49 for 2007. This indicates that the issues related to GAL-TAN had not yet fully coalesced into a single dimension before 2011 .

\section{Party closeness}

The variable measures if the respondent has a partisan social identity or not, by asking whether he or she feels close to any particular party. Those who answer yes to this question are categorized as feeling close to a party. No further grading of party closeness is used.

\subsection{Control variables}

I control for standard sociodemographic factors such as gender, age and level of education. For level of education, I have merged the varying categories into three groups: low (elementary school only), medium (everything between elementary school and a university degree), and high (university degree or equivalent). Furthermore, I control for residential area, i.e. whether the respondents lives in the countryside, in a population centre or in an urban setting (suburb or city). Political interest is measured on a 4-point scale and respondents are classified as having either high or low interest. Since Finland is bilingual, I also control for language group by using the question about native language to differentiate between Swedish-speakers and Finnish speakers.

\section{Results}

The results answer the four research questions formulated in the introduction. The first question asks whether the general level of AP has increased in Finland since the turn of the millennium. The development showed in figure 1 confirms that the feelings of the average Finnish voter towards the political parties have become markedly less neutral during the examined period from 2003 to 2019, resulting in a 26\% increase in AP (from a mean of 1,96 to 2,47 ) 
Figure 1. Average affective polarization as absence of neutrality 2003-2019.

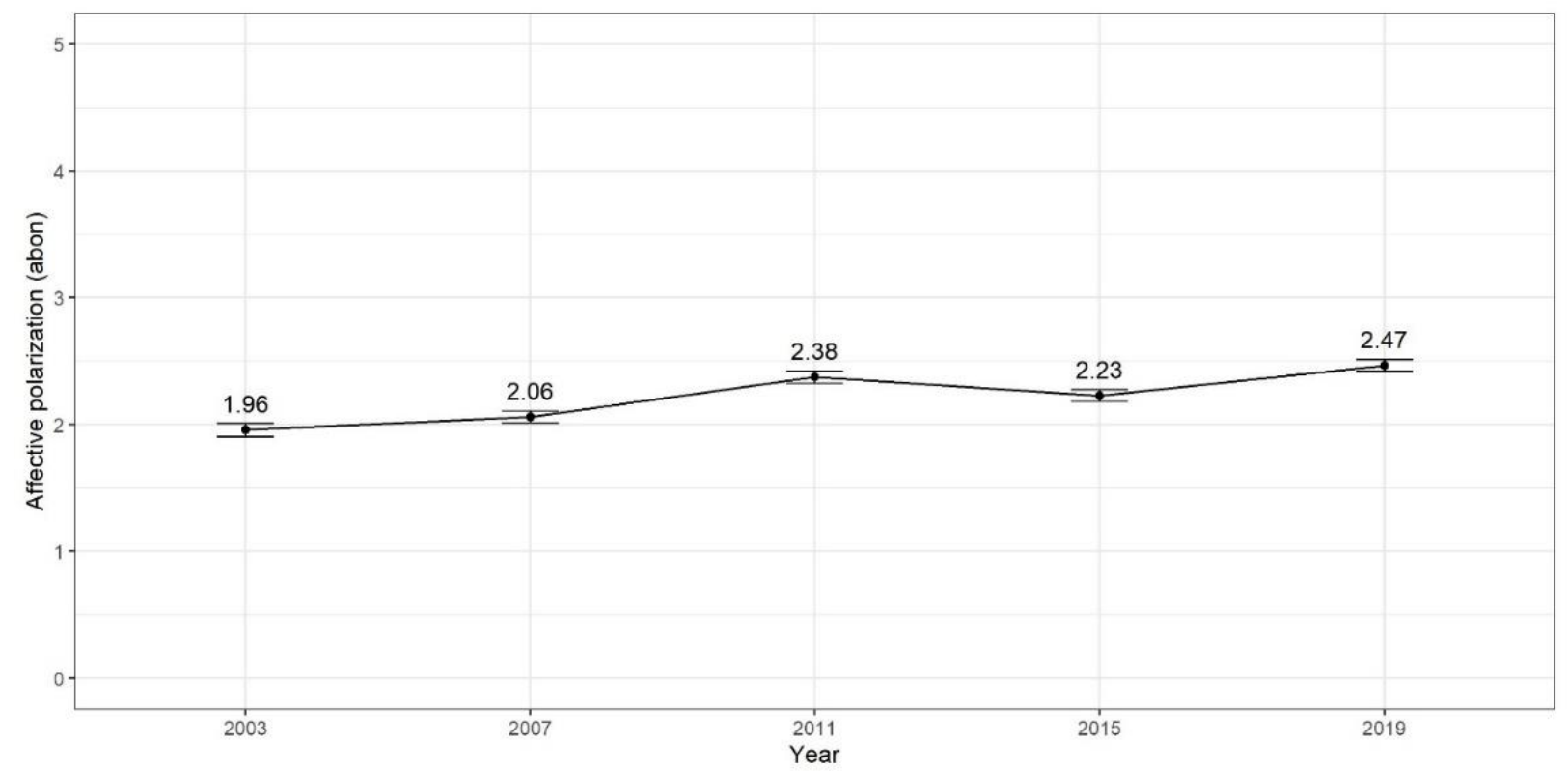

Note: a score of 0 means that every voter (dis)likes every party equally, while a score of 5 means that every voter considers every party to be either maximally disliked or maximally liked. The scores are calculated as weighted mean values with a 95\% confidence interval. Differences between subsequent years are statistically significant at $p<0,001$.

The second research question asks whether AP has increased broadly in the electorate, or if the development differs between groups of voters based on ideological position and partisan identity. An initial plot in figure 2 reveals that AP scores are roughly normally distributed around the mean value as it shifts over the period. This shows that the increase in affective polarization represents a general shift in the population, rather than the emergence of a smaller group of highly polarized voters.

Figure 2. Distribution of affective polarization 2003-2019

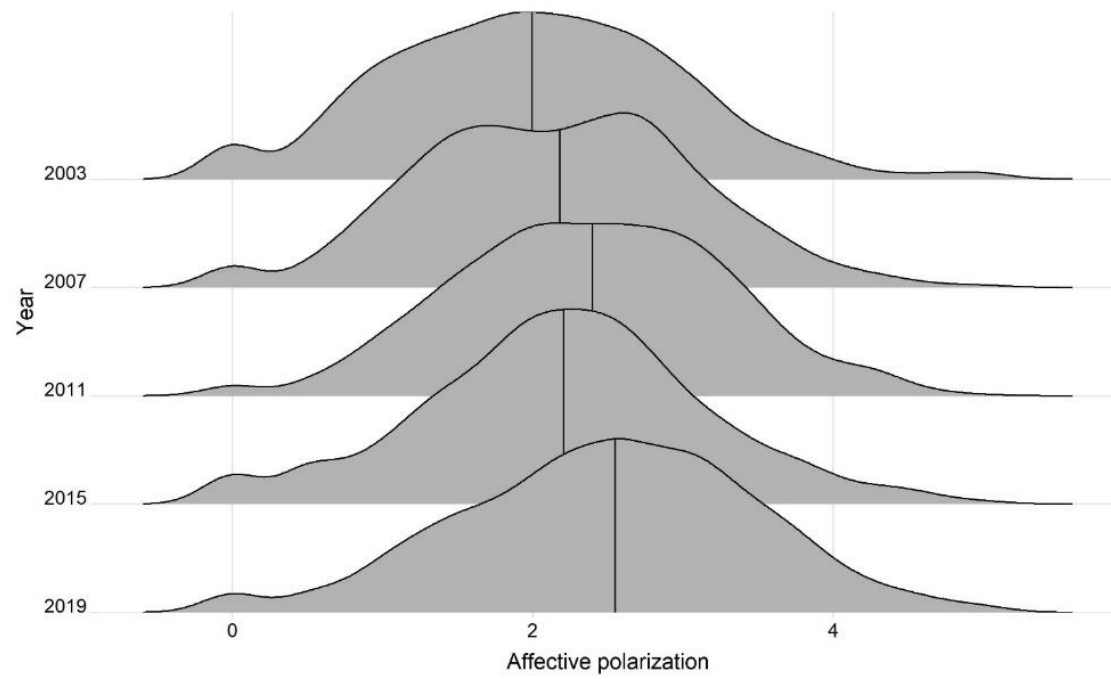

Next, I break the average AP score down into separate trends according to the voter categories defined by the dependent variables. I combine these trends with estimates of each group's proportion ${ }^{3}$ of the electorate during

\footnotetext{
${ }^{3}$ Proportions are calculated by using weights rather that the raw proportion of respondents in the sample. For 2003-2011, I have used weights calculated for respondents who answered the drop-off questionnaire.
} 
any given year, making it possible to assess whether the changing average is a result of changing levels of polarization in different groups, or a redistribution of voters between groups of different polarization levels.

Figure 3. Average AP and group size according to Left-right position 2003-2019.

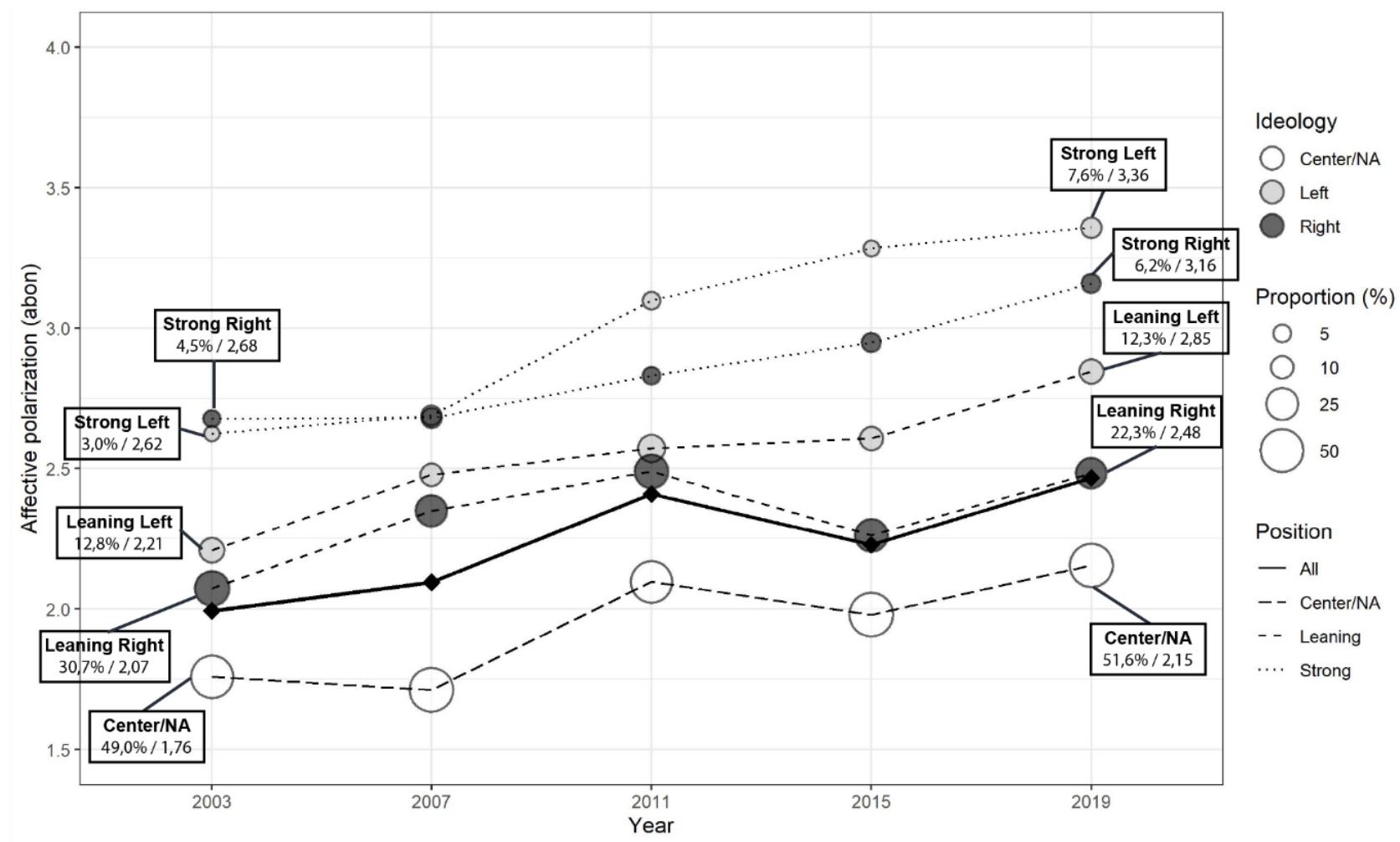

In figure 3, I group voters according to left-right category. In order to obtain an accurate estimate of the proportion of each group, I also include respondents with who did not answer the left-right item. These respondents are grouped together with the centrist voters, as their polarization characteristics are similar. The figure shows that the majority of voters fall into this category and that the average polarization trend by-andlarge follows the trend of this group of baseline voters.

Figure 3 furthermore shows that voters with strong ideological positions are clearly more polarized than leaners. While the strong right was most polarized in 2003 and 2007, the strong left jumped to the top position in 2011. Overall, there seems to be a substantial increase for all categories in the 2011 election, after which the left and the strong right continues to polarize. The right leaners and the broad centre, on the other hand, fall back into lower polarization in 2015 before once again becoming more polarized in 2019. Even though minor shifts in the distribution can be detected - for example a slight increase in respondents with strong positions it appears as if the changing affective polarization can be ascribed to generally increasing levels of AP rather than changing distributions. 
Figure 4. Average AP and group size according to GAL-TAN position 2003-2019.

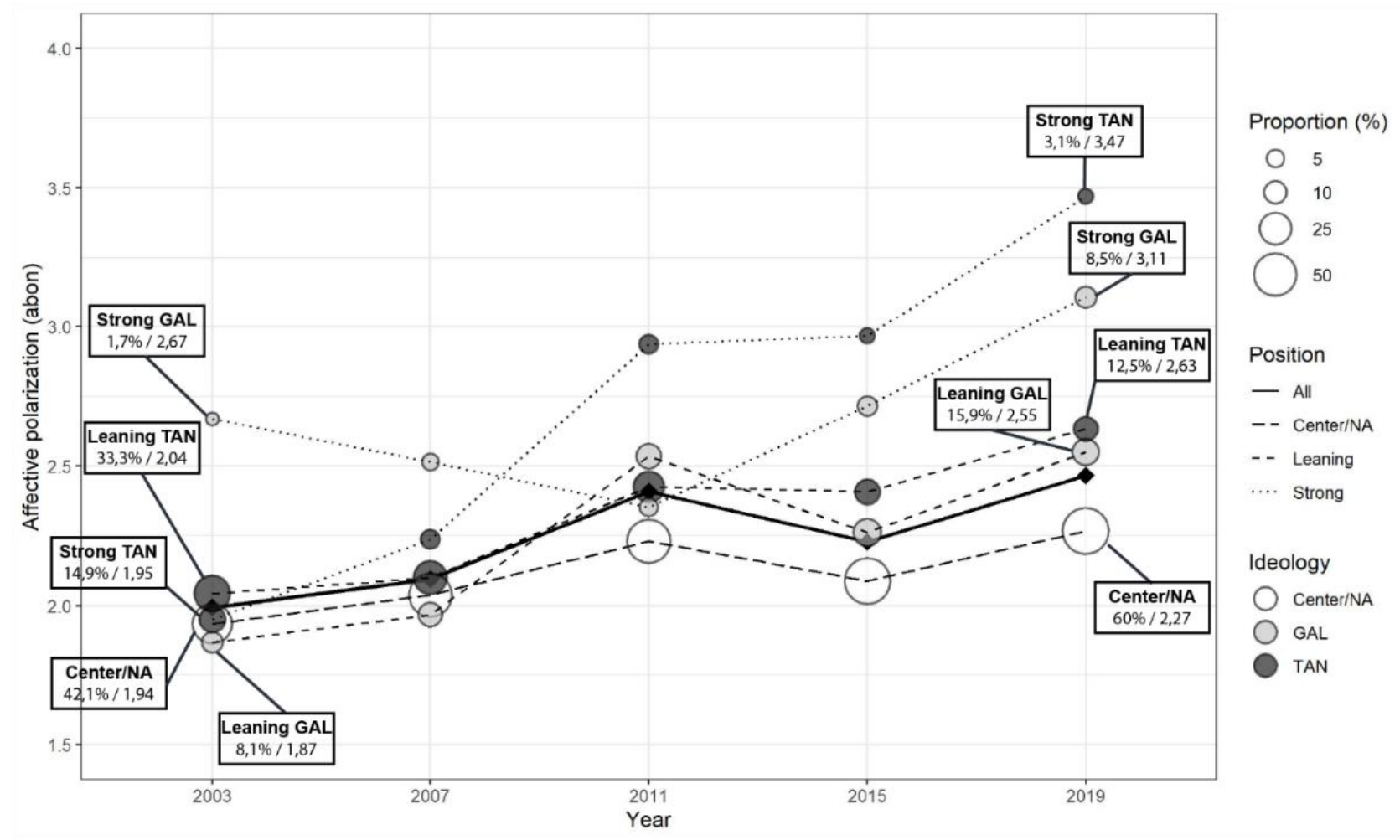

Figure 4 shows a corresponding visualization grouped according to GAL-TAN position. Here too, there is a substantial increase in polarization in 2011 for most groups. After this year, polarization increased primarily among respondents with strong positions. The increase has been greatest among strong TAN voters, although this group has decreased in numbers since 2003, constituting only a small portion $(3,1 \%)$ of the electorate in 2019. Strong GAL voters, on the other hand, where even fewer $(1,1 \%)$ in 2003 , but after the 2011 election this group has grown in both number and polarization level and constitute $8,5 \%$ of the electorate in 2019. A similar tendency can be seen among leaners; an increasing amount of GAL voters and a corresponding decrease on the TAN side. This indicates that the ideological balance is shifting towards the GAL position, leaving especially strong TAN voters increasingly marginalized and affectively polarized (see also Isotalo et al., 2019). Yet, although the small groups of respondents with strong positions manage to shift the overall trend somewhat upwards, it nonetheless mirrors that of the less polarized baseline voters who constitute around $60 \%$ of the electorate. 
Figure 5. Average AP and group size according to party closeness 2003-2019.

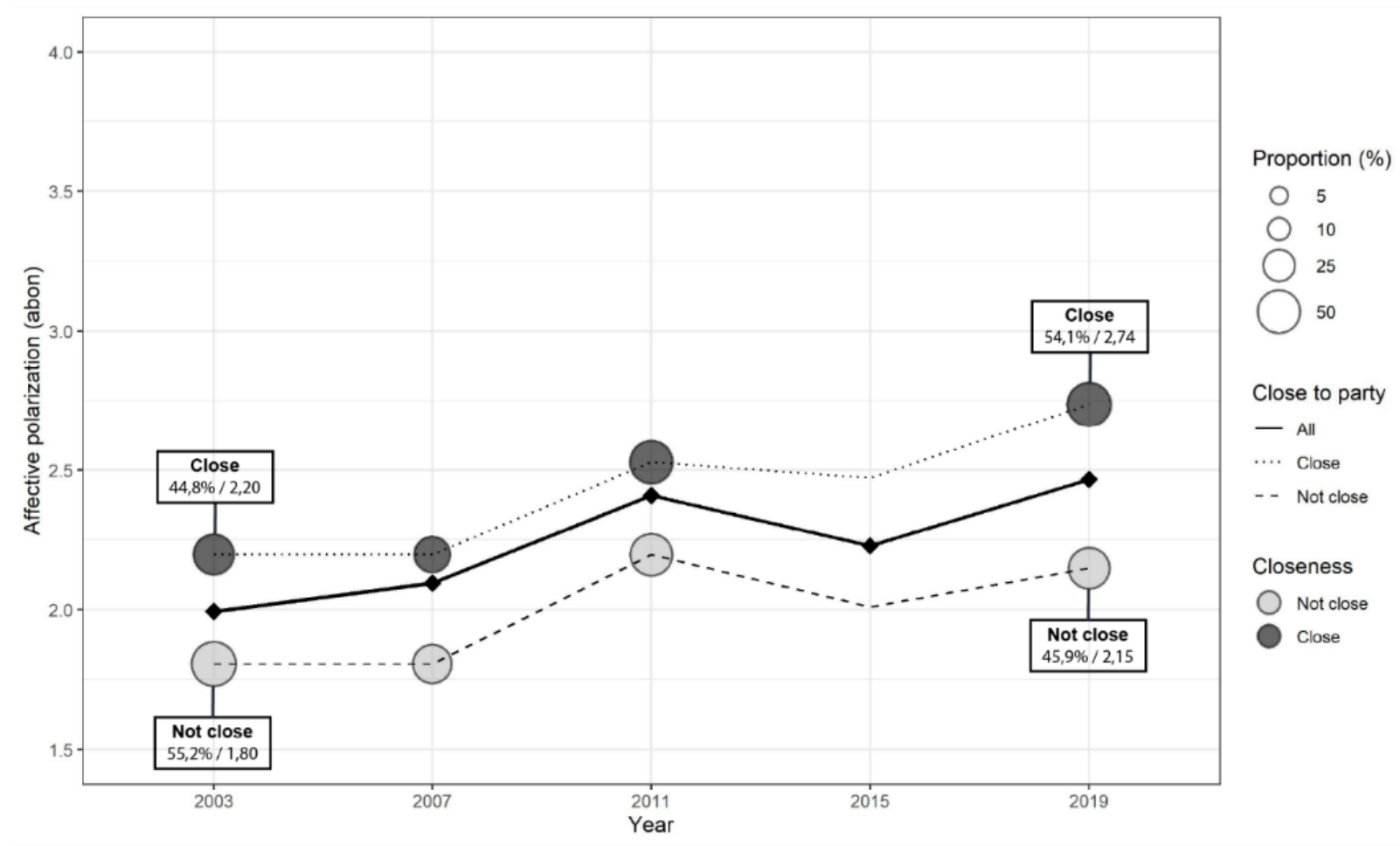

When grouping voters according to party closeness in figure 5, the results are straightforward. The proportion of voters who feel close to a party increase from roughly $44 \%$ to $54 \%$ over the period. There is a consistent gap between both voter groups, with partisan voters clearly more polarized than non-partisan voters. Yet, the polarization level of both groups change according to the same pattern over time along with the average trend. In sum, the increase in AP has taken place in all strata of the population, but more in some and less in other. The 2011 election stands out with a major overall increase in affective polarization, especially among strong left voters, who move from a position previously almost indistinguishable from left leaners, to surpassing the strong right and becoming the most polarized group. A corresponding major increase happened among voters with a strong TAN position, surpassing the strong GAL voters and making the group the most polarized on the GAL-TAN dimension. After 2011, both strong TAN and strong GAL voters have continued to polarize at a higher rate than the rest of the electorate. ${ }^{4}$

The third research question asked to what extent ideological position and partisan identity can explain differences in affective polarization among Finnish voters, while the fourth asks whether the effects of the variables change over time. These questions are best answered in tandem. However, the descriptive approach used above cannot provide the answers as there is significant overlap between the categories of the left-right dimension and those of the GAL-TAN dimension, both in turn overlapping with party closeness. To unpack the effects of the different variables and analyse them over time, I run a separate regression analysis of the main variables on affective polarization within each election year.

\footnotetext{
${ }^{4} \mathrm{~A}$ full table of average polarization scores and group proportions can be found in the online appendix B. Appendix C provides a further listing of polarization by party and year.
} 
Table 2. Yearly effects of party closeness and ideological position on affective polarization

\begin{tabular}{|c|c|c|c|c|c|}
\hline Predictors & $\begin{array}{c}2003 \\
\text { Estimates }\end{array}$ & $\begin{array}{c}2007 \\
\text { Estimates }\end{array}$ & $\begin{array}{c}2011 \\
\text { Estimates }\end{array}$ & $\begin{array}{c}2015 \\
\text { Estimates }\end{array}$ & $\begin{array}{c}2019 \\
\text { Estimates }\end{array}$ \\
\hline (Intercept) & $1.68 * * *$ & $1.87 * * *$ & $1.90 * * *$ & $1.89 * * *$ & $2.10 * * *$ \\
\hline Strong left & $0.72 * * *$ & $0.83 * * *$ & $0.85 * * *$ & $1.18 * * *$ & $0.91 * * *$ \\
\hline Leaning left & $0.27 *$ & $0.52 * * *$ & $0.36 * * *$ & $0.55 * * *$ & $0.53 * * *$ \\
\hline Leaning right & 0.14 & $0.47 * * *$ & $0.36 * * *$ & $0.28 * * *$ & $0.17 * *$ \\
\hline Strong right & $0.65 * * *$ & $0.75 * * *$ & $0.68 * * *$ & $0.85 * * *$ & $0.80 * * *$ \\
\hline Strong GAL & 0.41 & $0.41 * *$ & 0.30 & $0.43 * * *$ & $0.45 * * *$ \\
\hline Leaning GAL & -0.21 & -0.09 & $0.26 * *$ & $0.15 *$ & $0.17 *$ \\
\hline Leaning TAN & 0.08 & 0.05 & $0.26 * *$ & $0.24 * *$ & $0.50 * * *$ \\
\hline Strong TAN & 0.09 & $0.24 *$ & $0.54 * * *$ & $1.19 * * *$ & $1.27 * * *$ \\
\hline Feeling close to a party & $0.18 * *$ & $0.30 * * *$ & 0.11 & $0.23 * * *$ & $0.37 * * *$ \\
\hline Education: Medium & -0.16 & 0.07 & -0.08 & $-0.15 *$ & $-0.27 * * *$ \\
\hline $\begin{array}{l}\text { Education: High } \\
\text { Residential area: }\end{array}$ & -0.08 & 0.04 & -0.15 & -0.15 & $-0.24 * *$ \\
\hline Population Centre & 0.24 & -0.11 & -0.02 & -0.06 & -0.13 \\
\hline Residential area: City & 0.10 & $-0.21 *$ & 0.02 & -0.14 & -0.06 \\
\hline Gender: Male & -0.06 & $-0.15 * *$ & -0.01 & -0.04 & $-0.19 * * *$ \\
\hline Age $30-45$ & -0.18 & -0.15 & 0.05 & $0.19 *$ & $0.15 *$ \\
\hline Age 46-60 & 0.04 & -0.09 & 0.05 & 0.09 & $0.22 * *$ \\
\hline Age $>60$ & -0.03 & -0.08 & -0.14 & 0.00 & 0.02 \\
\hline Native language: Swedish & 0.01 & 0.22 & -0.16 & 0.17 & $0.25 * *$ \\
\hline Political interest: High & $0.32 * * *$ & 0.12 & $0.19 *$ & 0.07 & 0.07 \\
\hline Observations & 680 & 962 & 754 & 1344 & 1304 \\
\hline $\mathrm{R}^{2} / \mathrm{R}^{2}$ adjusted & $\begin{array}{l}0.143 / \\
0.118\end{array}$ & $\begin{array}{l}0.195 / \\
0.179\end{array}$ & $\begin{array}{l}0.157 / \\
0.136\end{array}$ & $\begin{array}{l}0.202 / \\
0.191\end{array}$ & $\begin{array}{l}0.300 / \\
0.290\end{array}$ \\
\hline
\end{tabular}

Note: The low number of observations in the first three years is caused by the GAL-TAN issues being placed in the dropoff questionnaire, which has a lower response rate. Separate weights that take this into account where used for these years. The reference categories are the Centre on the left-right and GAL-TAN scales, and voters not feeling close to a party.

Table 2 reveals several interesting results. First, the effects of having a strong ideological position, either on the left-right scale or the GAL-TAN scale, are substantially larger than for voters who merely lean in either direction. This confirms the role of ideological extremity in driving affective polarization. Second, the effects of ideological positions do indeed change from year to year, indicating that the context of each election can either boost or diminish the impact of different ideological positions on AP. The effect of feeling close to a party, on the other hand, appears to be more consistent. It temporarily disappears in 2011 but reaches its highest value in 2019, suggesting that the role of partisan identity as driver of affective polarization might be slightly growing.

The variations in effect on the left-right scale do not follow any discernible pattern, neither for leaners nor for respondents with a strong position. Rather, the effects fluctuate up and down with positions on the left having generally larger effects than corresponding positions on the right. The effects of the GAL-TAN positions tell a different story. The effect of holding a TAN position increases substantially between 2003 and 2019. From being statistically insignificant in 2003 , the effects catch up with and surpass the effects of GAL positions for 
both leaners and strong ideologues in 2011. In 2019, TAN-voters can be expected to be substantially more polarized than the corresponding GAL-voters.

On the GAL side, the development follows a less clear pattern. The effect of leaning GAL became significant in 2011, but then decreased in size. Strong GAL voters where significantly more polarized than the baseline voter already in 2007 and the effect was retained over the period, although it decreased somewhat in 2011 with a statistical significance of $p<0,1$. Overall, the GAL-TAN dimension became broadly relevant as a driver of AP in 2011. This is not surprising, given that Cronbach's alpha for the GAL-TAN index was low before this year, indicating that the dimension had either not formed at the time, or, to the extent that it had formed, had only a small effect for the most extreme voters.

\section{Concluding discussion}

This study originated from an identified research gap on affective polarization in Finland, a country that despite a tradition of consensus-like politics and no major ideological shifts is characterized by increasing worries about political polarization. I proposed that this could be explained by affective polarization, and set out to examine whether the emotional distances between supporters of different parties have been increasing since the turn of the millennium. Furthermore, I examined how the development is associated with ideological positions on the socioeconomic (left-right) and sociocultural (GAL-TAN) dimensions, as well as with having a partisan social identity. In doing so, I introduced a measure of AP that focuses on absence of neutrality towards parties, arguing that it offers improved conceptual validity in cases where a generalized individual measure is needed.

The results revealed that AP increased in Finland over the period, demonstrating that a tradition of consensus and low partisan hostility does not protect a country from the phenomena. The increase cannot be pinpointed to any specific ideological group. Rather, it has occurred broadly in the entire electorate; both among the substantial portion of voters who hold centrist views and among more ideologically extreme voters.

One possible consequence of this development is the undermining of the consensus culture in Finnish politics. If partisan animosity makes it more difficult for voters to accept compromises and coalitions with disliked opponents, it might reflect in the behaviour of parties during and after elections. Previous research (Im et al., 2019; Kekkonen \& Ylä-Anttila, 2021; Westinen \& Kestilä-Kekkonen, 2015) already indicates the existence of multiple loose blocs defined by similar positive and negative attitudes towards parties and these blocs might further solidify if attitudes become more hostile. On the micro level, increasing affective polarization might eventually lead to undesirable social behaviours such as discrimination and prejudice based on partisanship.

Nonetheless, it is important to remember that AP is increasing from a very low level. While political conflict is often unpleasant, it might in the case of Finland, also be viewed as a sign of increased engagement in politics; a corrective to the voter apathy resulting from political consensus culture. A country with no affective polarization at all would be a country where citizens feel no emotional connection to politics. It is thus premature to sound the alarm bells too loudly based on the current increase in AP. Rather, the development singles Finland out as an important and interesting case for further studies of how affective polarization increases in a low-hostility context.

The results showed that feeling close to a party also contributes to affective polarization, albeit not as strongly as ideology. This is somewhat surprising, given the weight assigned to partisan identities in the literature. Yet, 
the low impact of partisan identity does not necessarily mean that the role of identities should be downplayed. Rather, political identities can take on forms that transcend partisan identities, such as more diffuse bloc or ideological identities. It is thus possible that the impact of ideology can be attributed not only to 'principled dislike' of opposing opinions, but to some extent also to group hostility based on ideological identities (see for example Popp \& Rudolph, 2011 on symbolic ideology). This calls for further research into the interplay and alignment between ideological beliefs, political identities and polarization.

Lastly, the results identified the election year of 2011 as a watershed year with a major increase in AP and a fundamental shift in the character of Finnish politics, as the GAL-TAN dimension became a substantive driver of affective polarization. A minor cool down followed in 2015, but then AP increased again and reached even higher levels in 2019. This year, GAL-TAN was an equally important driver of AP as the left-right division. These shifting effects of ideological positions, in turn, point towards the need for further research into contextual factors behind affective polarization. In addition, further studies might reveal whether the increase in 2019 represents an ongoing trend, or if it is merely a fluctuation around a new normal established in 2011.

\section{Acknowledgements}

I thank Åsa von Schoultz and Staffan Himmelroos for their patient support, and Arto Kekkonen for his useful comments. 


\section{References}

Abramowitz, A. I., \& Webster, S. W. (2018). Negative Partisanship: Why Americans Dislike Parties But Behave Like Rabid Partisans. Political Psychology. https://doi.org/10.1111/pops.12479

Borg, S. (2012). Perussuomalaiset. In S. Borg (Ed.), Muutosvaalit 2011. Ministry of Justice.

Borg, S., Kestilä-kekkonen, E., \& Wass, H. (2020). Johdanto: mikä politiikan ilmastonmuutos? In S. Borg, E. Kestilä-kekkonen, \& H. Wass (Eds.), Politiikan ilmastonmuutos. Eduskuntavaalitutkimus 2019 (pp. 4565). Ministry of Justice. http://urn.fi/URN:ISBN:978-952-259-838-7

Borg, S., \& Paloheimo, H. (2009). Johdanto. In S. Borg \& H. Paloheimo (Eds.), Vaalit yleisödemokratiassa (pp. 13-27). Tampere University Press.

Bougher, L. D. (2017). The Correlates of Discord: Identity, Issue Alignment, and Political Hostility in Polarized America. In Political Behavior (Vol. 39, Issue 3). Springer US. https://doi.org/10.1007/s11109016-9377-1

Dalton, R. J. (2008). The Quantity and the Quality of Party Systems. Party System Polarization, Its Measurement, and Its Consequences. Comparative Political Studies, 41(7), 1-22. https://doi.org/10.1177/0010414008315860

Fornaro, P. (2021). Onko Suomalainen politiikka polarisoitunut? https://bibu.fi/wp/wpcontent/uploads/2021/01/BIBUpolarisaatioBrief.pdf

Garry, J. (2007). Making "party identification" more versatile: Operationalising the concept for the multiparty setting. Electoral Studies, 26(2), 346-358. https://doi.org/10.1016/j.electstud.2006.07.003

Gidron, N., Adams, J., \& Horne, W. (2020). American Affective Polarization in Comparative Perspective. Cambridge University Press. https://doi.org/10.1017/9781108914123

Grönlund, K. (2016). Eduskuntavaalit 2015. In K. Grönlund \& H. Wass (Eds.), Eduskuntavaalitutkimus 2015 (pp. 58-75). Ministry of Justice. http://urn.fi/URN:ISBN:978-952-259-517-1

Hagevi, M. (2015). Bloc Identification in Multi-Party Systems: The Case of the Swedish Two-Bloc System. West European Politics, 38(1), 73-92. https://doi.org/10.1080/01402382.2014.911480

Hämäläinen, U. (2016). Neljän vuoden mittainen hallituspiina. In K. Grönlund \& H. Wass (Eds.), Eduskuntavaalitutkimus 2015 (pp. 46-57). Ministry of Justice. http://urn.fi/URN:ISBN:978-952-259$517-1$

Hansen, K. M., \& Kosiara-Pedersen, K. (2017). How campaigns polarize the electorate: Political polarization as an effect of the minimal effect theory within a multi-party system. Party Politics, 23(3), 181-192. https://doi.org/10.1177/1354068815593453

Harteveld, E. (2021). Fragmented foes: Affective polarization in the multiparty context of the Netherlands. Electoral Studies, 71(April), 102332. https://doi.org/10.1016/j.electstud.2021.102332

Hernández, E., Anduiza, E., \& Rico, G. (2019). Affective polarization and the saliency of elections. APSA Annual Conference, June, 1-35. https://doi.org/10.1016/j.electstud.2020.102203

Hooghe, L., Marks, G., \& Wilson, C. J. (2002). Does left/right structure party positions on european integration? Comparative Political Studies, 35(8), 965-989. https://doi.org/10.1177/001041402236310

Huddy, L., Mason, L., \& Aarøe, L. (2015). Expressive Partisanship: Campaign Involvement, Political Emotion, and Partisan Identity. American Political Science Review, 109(1), 1-17. https://doi.org/10.1017/S0003055414000604

Im, Z., Kantola, A., Kauppinen, T., \& Wass, H. (2019). Neljän kuplan kansa. https://bibu.fi/neljan-kuplankansa-miten-suomalaiset-aanestavat/

Isotalo, V., Järvi, T., Von Schoultz, Å., \& Söderlund, P. (2019). The Finnish Voter 2003-2019. 
https://www.vaalitutkimus.fi/wp-content/uploads/2020/12/OM_Suomalainen_aanestaja_2ndedition_dec-2020.pdf

Isotalo, V., Söderlund, P., \& von Schoultz, Å. (2020). Polarisoituuko politiikka Suomessa? Puolueiden äänestäjäkuntien arvosiirtymät 2003-2019. In S. Borg, E. Kestilä-kekkonen, \& H. Wass (Eds.), Politiikan ilmastonmuutos. Eduskuntavaalitutkimus 2019 (pp. 288-306). Ministry of Justice.

Iyengar, S., \& Krupenkin, M. (2018). The Strengthening of Partisan Affect. Political Psychology, 39, 201218. https://doi.org/10.1111/pops.12487

Iyengar, S., Lelkes, Y., Levendusky, M., Malhotra, N., \& Westwood, S. J. (2018). The Origins and Consequences of Affective Polarization in the United States. Annual Review of Political Science, 1-35. https://doi.org/10.1146/annurev-polisci-051117-073034

Iyengar, S., Sood, G., \& Lelkes, Y. (2012). Affect, Not Ideology: A Social Identity Perspective on Polarization. Public Opinion Quarterly, 76(3), 405-431. https://doi.org/10.1093/poq/nfs038

Iyengar, S., \& Westwood, S. J. (2015). Fear and Loathing across Party Lines: New Evidence on Group Polarization. American Journal of Political Science, 59(3). https://doi.org/10.1111/ajps.12152

Jungar, A. C. (2002). A case of a surplus majority government: The Finnish rainbow coalition. Scandinavian Political Studies, 25(1), 57-83. https://doi.org/10.1111/1467-9477.00063

Karvonen, L. (2014). Parties, Governments and Voters in Finland. Politics under fundamental societal transformation. ECPR Press.

Kekkonen, A., \& Ylä-Anttila, T. (2021). Affective blocs : Understanding affective polarization in multiparty systems. Electoral Studies, 72. https://doi.org/10.1016/j.electstud.2021.102367

Knudsen, E. (2020). Affective Polarization in Multiparty Systems? Comparing Affective Polarization Towards Voters and Parties in Norway and the United States. Scandinavian Political Studies. https://doi.org/10.1111/1467-9477.12186

Levendusky, M., \& Malhotra, N. (2016). Does Media Coverage of Partisan Polarization Affect Political Attitudes? Political Communication, 33(2), 283-301. https://doi.org/10.1080/10584609.2015.1038455

Mason, L. (2015). "I disrespectfully agree": The differential effects of partisan sorting on social and issue polarization. American Journal of Political Science, 59(1), 128-145. https://doi.org/10.1111/ajps.12089

Mason, L. (2016). A cross-cutting calm: How social sorting drives affective polarization. Public Opinion Quarterly, 80(Specialissue1), 351-377. https://doi.org/10.1093/poq/nfw001

McCoy, J., \& Somer, M. (2019). Toward a Theory of Pernicious Polarization and How It Harms Democracies: Comparative Evidence and Possible Remedies. Annals of the American Academy of Political and Social Science, 681(1), 234-271. https://doi.org/10.1177/0002716218818782

Mickelsson, R. (2015). Suomen puolueet. Vapauden ajasta maailmantuskaan. Kustannusosakeyhtiö Vastapaino.

Moring, T., \& Mykkänen, J. (2009). Vaalikampanja. In S. Borg \& H. Paloheimo (Eds.), Vaalit yleisödemokratiassa (pp. 28-59). Tampere University Press.

Pesonen, P., \& Borg, S. (2005). Eduskuntavaalit 2003. In H. Paloheimo (Ed.), Vaalit ja demokratia Suomessa (pp. 28-45). WSOY.

Popp, E., \& Rudolph, T. J. (2011). A tale of two ideologies: Explaining public support for economic interventions. Journal of Politics, 73(3), 808-820. https://doi.org/10.1017/S0022381611000478

Railo, E., \& Ruohonen, S. (2016). Vaalikampanjat ja julkisuuden agenda. In K. Grönlund \& H. Wass (Eds.), Eduskuntavaalitutkimus 2015 (pp. 76-94). Ministry of Justice. http://urn.fi/URN:ISBN:978-952-259$517-1$

Reiljan, A. (2016). Affective Polarization in European Party Systems. ECPR Graduate Student Conference 
Papers. https://ecpr.eu/Filestore/PaperProposal/c588a466-ecdd-48f4-a127-dfc5db37f909.pdf

Reiljan, A. (2020). "Fear and loathing across party lines" (also) in Europe: Affective polarisation in European party systems. European Journal of Political Research, 59(2), 376-396. https://doi.org/10.1111/14756765.12351

Reiljan, A., \& Ryan, A. (2021). Ideological Tripolarization, Partisan Tribalism and Institutional Trust: The Foundations of Affective Polarization in the Swedish Multiparty System. Scandinavian Political Studies, O(0), 1-25. https://doi.org/10.1111/1467-9477.12194

Renström, E. A., Bäck, H., \& Schmeisser, Y. (2020). Vi gillar olika. Om affektiv polarisering bland svenska väljare. In U. Andersson, A. Carlander, \& P. Öhberg (Eds.), Regntunga skyar - SOM-undersökningen 2019 (pp. 427-443). The SOM Institute (University of Gothenburg).

Rogowski, J. C., \& Sutherland, J. L. (2016). How Ideology Fuels Affective Polarization. Political Behavior, 38(2), 485-508. https://doi.org/10.1007/s11109-015-9323-7

Ryan, A., \& Reiljan, A. (2018). Åsikts- och känslomässig polarisering1985-2014. In D. Karlsson (Ed.), Folkets främsta företrädare (pp. 129-149). Göteborgs universitet.

Strandberg, K., \& Borg, S. (2020). Internet ja sosiaalinen media osana vaalikampanjaa. In S. Borg, E. Kestiläkekkonen, \& H. Wass (Eds.), Politiikan ilmastonmuutos. Eduskuntavaalitutkimus 2019 (pp. 103-122). Ministry of Justice. http://urn.fi/URN:ISBN:978-952-259-838-7

Tajfel, H., \& Turner, J. (1979). An Integrative Theory of Intergroup Conflict. In W. G. Austinand \& S. Worchel (Eds.), The Social Psychology of Inter-group Relations (pp. 33-79). Brooks-Cole.

Wagner, M. (2020). Affective polarization in multiparty systems. Electoral Studies. https://doi.org/10.1016/j.electstud.2020.102199

Ward, D. G., \& Tavits, M. (2019). How partisan affect shapes citizens' perception of the political world. Electoral Studies, 60(November 2018), 102045. https://doi.org/10.1016/j.electstud.2019.04.009

Westinen, J., \& Kestilä-Kekkonen, E. (2015). Perusduunarit, vihervasemmisto ja porvarit: suomalaisen äänestäjäkunnan jakautuminen ideologisiin blokkeihin vuoden 2011 eduskuntavaaleissa. Politiikka, 57(2), 94-114.

Westinen, J., Kestilä-kekkonen, E., \& Tiihonen, A. (2016). Äänestäjät arvo- ja asenneulottuvuuksilla. In K. Grönlund \& H. Wass (Eds.), Poliittisen osallistumisen eriytyminen. Eduskuntavaalitutkimus 2015. (Vol. 1, pp. 273-297). Ministry of Justice.

Winter, N., \& Berinsky, A. (1999). What's Your Temperature? Thermometer Ratings and Political Analysis. Paper Presented at the Annual Meeting of the American Political Science Association. www.nicholasjgwinter.com/assets/papers/Winter-Berinsky-1999.pdf

\section{Data}

Borg, Sami (University of Tampere) \& Grönlund, Kimmo (Åbo Akademi University): Finnish National Election Study 2011 [dataset]. Version 3.0 (2018-08-27). Finnish Social Science Data Archive [distributor]. http://urn.fi/urn:nbn:fi:fsd:T-FSD2653

Grönlund, Kimmo (Åbo Akademi University) \& Borg, Sami (Tampere University): Finnish National Election Study 2019 [dataset]. Version 1.0 (2020-09-30). Finnish Social Science Data Archive [distributor]. http://urn.fi/urn:nbn:fi:fsd:T-FSD3467 
Grönlund, Kimmo (Åbo Akademi University) \& Kestilä-Kekkonen, Elina (University of Tampere): Finnish National Election Study 2015 [dataset]. Version 2.0 (2018-07-24). Finnish Social Science Data Archive [distributor]. http://urn.fi/urn:nbn:fi:fsd:T-FSD3067

Karvonen, Lauri (Åbo Akademi University) \& Paloheimo, Heikki (University of Tampere): Finnish National Election Study 2003 [dataset]. Version 1.1 (2012-01-05). Finnish Social Science Data Archive [distributor]. http://urn.fi/urn:nbn:fi:fsd:T-FSD1260

Paloheimo, Heikki (University of Tampere): Finnish National Election Study 2007 [dataset]. Version 2.0 (2018-07-12). Finnish Social Science Data Archive [distributor]. http://urn.fi/urn:nbn:fi:fsd:T-FSD2269

\section{Supporting information}

Additional supporting information may be found in the online version of this article at the publisher's web site: Appendix A: Descriptive statistics of the data and main variables

Appendix B: Voters grouped by main variables and year: percentage of electorate and AP level Appendix C: Affective polarization of party supporters

Appendix D: Description of the GAL-TAN index

Appendix E: Comparison of affective polarization measures 